\title{
DETERMINAN ENVIRONMENTAL DISCLOSURES PERUSAHAAN MANUFAKTUR DI INDONESIA DAN MALAYSIA
}

\begin{abstract}
The study aims to examine the influence of corporate governance mechanism, company size and financial performance towards environmental disclosures in manufacturing companies listed in Indonesia Stock Exchange and Bursa Malaysia period 2016.The variables examined in this study are managerial ownership, size of the board of commissioners, company size, and liquidity. The research used purposive sampling method, obtained from 59 Indonesia manufacture companies and 63 Malaysia manufactures companies. The examination used multiple regression analysis and independent sample t test. The result of the research:1) The managerial ownership had negative influence towards environmental disclosures in Indonesia, but it had positive influence in Malaysia, 2) The size of the board of commissioners had positive influence towards environmental disclosures in Indonesia, but it did not have influence in Malaysia, 3) The size of the company did not have influence towards environmental disclosures in Indonesia, but it had positive influence in Malaysia,4) The liquidity had negative influence towards environmental disclosures in Indonesia, but it had positive influence in Malaysia, and5) There was difference in the level of environmental disclosures in Indonesia and in Malaysia.
\end{abstract}

Keywords: managerial ownership, size of the board of commissioners, number of meetings of the board of commissioners, company size, profitability, liquidity, environmental disclosures.

\section{LATAR BELAKANG PENELITIAN}

Masalah tentang pencemaran lingkungan patut diperhatikan bagi stakeholders maupun shareholders. Pada umumnya investor lebih memilih perusahaan yang memerhatikan aspek lingkungan (Suhardjanto dan Permatasari, 2010). Lingkungan merupakan bagian penting dalam menentukan kualitas, kuantitas, serta keberlangsungan masa depan perusahaan dan aktivitas manusia. Perusahaan perlu melaporkan aktivitasaktivitas terkait dengan penanganan lingkungan (Tze et al., 2015)

Di Indonesia terdapat kasus yang timbul akibat pencemaran lingkungan. Wahana Lingkungan Hidup (WALHI) tahun 2017 menyatakan sekitar 30 pabrik membuang limbah sembarangan ke sungai akibatnya sungai citarum sepanjang $10 \mathrm{~km}$ yang berada di Bandung tercemar dan dalam kondisi yang memprihatinkan. Menurut Sindonews tahun 2016 PT Putera Restu lbu Abadi adalah perusahaan pengolahan limbah bahan berbahaya dan beracun perusahaan tersebut melakukan pencemaran lingkungan. Air sumur di pemukiman warga menjadi tercemar, dan timbul bau busuk yang menyengat. Perusahaan tersebut melakukan penimbunan limbah bahan berbahaya dan beracun ke dalam tanah. Penimbunan tersebut tidak memiliki izin dari pemerintah.

PT Arutmin Indonesia pada tahun 2014 perusahaan tersebut mencemari lingkungan akibat aktivitas pertambangan perusahaan. Pencemaran itu berdampak pada aliran sungai yang berada di Kalimantan Selatan. Akibatnya air sungai menjadi kotor, tanah menjadi tandus, serta pohon-pohon yang berada disekitar sungai 
menjadi mati. Selain itu kasus pencemaran lingkungan melibatkan perusahaan Malaysia terjadi di Riau. Tahun 2014 PT Adei Plantation and Industry terbukti melakukan kelalaian mengakibatkan kerusakan lingkungan, sekitar 40 ha lahan di Kabupaten Pelalawan mengalami kebakaran.

Kasus pencemaran lingkungan merupakan dampak negatif yang timbul dari aktivitas perusahaan. Berdasarkan fenomena ini, maka perusahaan kemudian didorong oleh masyarakat dan pemerintah agar lebih memperhatikan aspek kelestarian lingkungan. Selain itu, perusahaan juga dituntut untuk mengungkapkan (disclose) informasi lingkungan terkait dengan aktivitas perusahaan yang berkaitan dengan lingkungan. Perusahaan penting melakukan pengungkapan karena untuk meningkatkan citra perusahaan yang lebih baik dimata masyarakat luas (Suhardjanto dan Miranti, 2009). Pengungkapan yang dituntutkan ini kemudian dikenal dengan istilah environmental disclosures. Environmental disclosures sendiri didefinisikan sebagai pengungkapan informasi di dalam laporan tahunan perusahaan yang berkaitan dengan lingkungan hidup (Suratno et al., 2006). Environmental disclosures menjelaskan kepatuhan terhadap hukum tentang lingkungan, peraturan dan norma, serta program untuk perlindungan lingkungan dan konservasi sumber daya alam. Oleh karena itu, menjadi penting bahwa perusahaan harus melakukan pengungkapan terkait lingkungan (Said et al.,2013).

Ikatan Akuntan Indonesia (IAI) melalui pernyataan yang terkandung dalam Pernyataan Standar Akuntansi Keuangan (PSAK) Nomor 1 (2012) paragraf 9 menyatakan bahwa :“Entitas dapat pula menyajikan laporan yang terpisah dari laporan keuangan seperti laporan mengenai lingkungan hidup dan laporan nilai tambah (value added statement), khususnya bagi industri dimana faktor-faktor lingkungan hidup memegang peranan penting dan bagi industri yang menganggap karyawan sebagai kelompok pengguna laporan yang memegang peranan penting".

Pedoman pelaporan lingkungan di Malaysia adalah Dewan Standar Akuntansi Malaysia atau Malaysia Accounting Standard Board (MASB) 1 dan 20. MASB 1, par. 10 membuat referensi eksplisit laporan lingkungan mendorong perusahaan untuk menyajikan informasi tambahan jika manajemen berpendapat mereka akan membantu pengguna dalam membuat keputusan ekonomi. MASB 20 memberikan persyaratan pengungkapan untuk pengakuan kewajiban dan aset kontinjensi. Meskipun MASB 20 tidak memberikan rincian spesifik tentang jenis kewajiban, hal itu diduga bahwa kewajiban lingkungan berpotensi dimasukkan dalam laporan tahunan. Meskipun persyaratan MASB 1 dan 20 telah diberlakukan akan tetapi pelaporan lingkungan masih inisiatif sukarela di Malaysia (Putri, 2015)

Pemerintahan Malaysia melakukan upaya untuk meningkatkan kepedulian dan kesadaran masyarakatnya untuk memperhatikan dampak pencemaran lingkungan. Pemerintah Malaysia melalui lembaga kemasyarakatan untuk ikut serta berperan dalam pelestarian lingkungan. Mereka intens mengawasi cakupan permasalahan dampak lingkungan seperti pembuangan limbah beracun, pembakaran lahan, erosi tanah yang mengakibatkan kerusakan lingkungan. Masyarakat yang sadar akan kepedulian terhadap isu-isu lingkungan maka akan mendorong pihak perusahaan untuk mengungkapkan lingkungannya dalam laporan tahunan perusahaan (Nik dan Sulaiman, 2004).

Environmental disclosures saat ini masih bersifat sukarela, hal ini menyebabkan adanya saling tuding dan 
lempar tanggungjawab antara pemerintah, perusahaan dan masyarakat terhadap kerusakan lingkungan yang terjadi. Environmental disclosures juga menuai banyak kritik, tidak hanya di Indonesia saja bahkan di dunia. Pengungkapan tersebut dianggap self-serving dan tidak teliti dalam melaporkan kinerja lingkungan perusahaan. Oleh karena itu, hingga detik ini belum ada sistem dan format yang disepakati secara universal dalam pengungkapan lingkungan. Didukung dengan aturan bahwa pelaporan tersebut hanya sebatas sukarela sehingga memungkinkan perusahaan untuk tidak melakukan pengungkapan dan pelaporan terkait permasalahan lingkungan (Oktafianti dan Rizki, 2015)

Penelitian terdahulu terkait dengan environmental disclosures sudah banyak dilakukan, namun dalam hal ini masih banyak yang perlu dikembangkan dan diteliti kembali. Hal ini mengingat masalah terkait lingkungan hidup yang terjadi masih tergolong cukup tinggi. Hal ini bertujuan agar masalah terkait dengan lingkungan hidup bisa segera diatasi. Upaya tersebut dilakukan dengan memberikan masukan dan bukti terkait dengan penelitian environmental disclosures. Maka dari itu, diharapkan bisa dijadikan pedoman bagi pihak-pihak yang berkepentingan yang berhubungan langsung menangani masalah pencemaran lingkungan. Selain itu, menarik untuk diteliti tentang apa saja yang dapat mempengaruhi environmental disclosures. Ada beberapa mekanisme corporate governance yang diduga mempengaruhi environmental disclosures.

Mekanisme corporate governance adalah tata cara pengelolaan perusahaan yang disusun untuk mengatur jalannya operasi perusahaan. Selain itu, melindungi kepentingan stakeholders dan shareholers, serta dapat mengontrol tindakan manajer dalam pengelolaannya terhadap perusahaan. Mekasnisme corporate governance dalam penelitian ini adalah kepemilikan manajerial dan ukuran dewan komisaris. Menurut Fama dan Jensen (1983), semakin tinggi tingkat kepemilikan manajerial, maka semakin tinggi pula motivasi untuk mengungkapkan aktivitas yang dilakukan perusahaan. Termasuk tentang aktivitas yang berkaitan dengan tanggung jawab lingkungan. Perusahaan melakukan pengungkapan tentang aktivitas yang dilakukan karena dapat meningkatkan citra perusahaan yang pada akhirnya akan berdampak positif bagi kesejahteraan manajer selaku pemegang saham.

Penelitian oleh Mardiyatnolo et al. (2015) menemukan bahwa kepemilikan manajerial tidak memiliki pengaruh terhadap environmental disclosures. Hal ini karena ada atau tidaknya kepemilikan manajerial tidak memengaruhi pengungkapan informasi lingkungan. Oktafianti dan Rizki (2015) menemukan bahwa adanya pengaruh positif kepemilikan manajerial terhadap environmental disclosures. Anggraini (2006) menemukan bahwa adanya pengaruh positif kepemilikan manajerial terhadap environmental disclosures. Kepemilikan manajer yang semakin besar di dalam perusahaan membuat manajer lebih memikirkan kepentingan dan kesejahteraan pemegang saham.

Dewan komisaris berfungsi mengawasi apakah manajemen bertindak sesuai dengan tujuan perusahaan serta menasehati direksi dalam pengambilan keputusan yang berkaitan dengan pengambilan keputusan apakah manajemen melakukan pengungkapan lingkungan atau tidak (Prasetianti, 2014). Penelitian Arta dan Sari (2015) menemukan bahwa ukuran dewan komisaris memiliki pengaruh positif terhadap luas pengungkapan lingkungan. Semakin banyak pengawasan terhadap aktivitas perusahaan akan membuat perusahaan menjadi lebih tertib dalam pengungkapan. Penelitian di Malaysia Said et al. (2013) menemukan 
ukuran dewan komisaris berpengaruh negatif terhadap environmental disclosures.

Pada umumnya perusahaan yang besar lebih luas dalam melakukan environmental disclosures. Perusahaan memiliki aset yang lebih besar sehingga mereka akan melakukan aktivitas tanggungjawab sosialnya terhadap lingkungan dibandingkan dengan perusahaan kecil (Oktafianti dan Rizki, 2015). Penelitian Smith et al. (2007) hasilnya menunjukkan bahwa ukuran perusahaan berpengaruh positif terhadap environmental disclosures. Solikhah dan Winarsih (2015) menemukan bahwa ukuran perusahaan berpengaruh positif terhadap environmental disclosures. Ukuran perusahaan yang besar maka akan berpengaruh besar terhadap aktivitas operasi perusahaan di masyarakat. Hal ini sangat dimungkinkan memiliki pemegang saham yang lebih memperhatikan program-program sosial dan lingkungan yang dibuat oleh perusahaan. Bertolak belakang dengan penelitian Anggraini (2006) menemukan ukuran perusahaan tidak berpengaruh terhadap pengungkapan sosial dan lingkungan perusahaan. Hal ini karena yang dijadikan dasar atas hasil pengujian adalah perusahaan besar belum tentu melakukan environmental disclosures yang luas. Apabila perusahaan tersebut tidak menganggap bahwa kebijakan environmental disclosures sebagai kebijakan yang menguntungkan.

Menurut Iswandika et al.(2014), perusahaan yang memiliki rasio likuiditas tinggi akan melakukan berbagai kegiatan sosial dan lingkungan. Pengungkapan tersebut sebagai sinyal bahwa perusahaan tersebut lebih baik daripada perusahaan lain. Berbagai kegiatan sosial dan lingkungan tersebut kemudian diungkapkan dalam laporan keuangan. Maka dari itu, seharusnya rasio likuiditas berbanding lurus dengan tingkat environmental disclosures. Syahrir dan Suhendra (2010) menemukan bahwa likuiditas berpengaruh positif terhadap CSR disclosures. Penelitian ini akan menguji pengaruh likuiditas terhadap environmental disclosures. Penelitian Maiyarni et al.(2014) menemukan bahwa adanya pengaruh negatif likuiditas terhadap CSR disclosures. Perusahaan yang memiliki likuditas yang tinggi enggan melakukan environmental disclosures karena sudah merasa cukup puas dengan kinerja keuangannya. Ekowati et al. (2014) menunjukkan bahwa likuiditas tidak berpengaruh terhadap CSR disclosures

Penelitian ini mengacu pada Oktafianti dan Rizki (2015). Perbedaan penelitian ini dengan penelitian Oktafianti dan Rizki (2015), adalah terletak pada variabel independen, sampel penelitian, dan periode tahun sampel. Penelitian ini menambah variabel independen yaitu, ukuran dewan komisaris, jumlah rapat dewan komisaris, dan likuiditas. Penelitian ini menggunakan sampel perusahaan manufaktur yang terdaftar di Bursa Efek Indonesia dan Bursa Malaysia tahun 2016. Alasan menggunakan sampel perusahaan manufaktur adalah karena perusahaan manufaktur lebih luas dalam pengungkapan lingkungan dan memiliki dampak yang cukup besar terkait dengan pencemaran lingkungan akibat limbah pabrik yang dihasilkan. Selain itu penelitian ini juga membandingan tingkat environmental disclosures di Indonesia dan Malaysia. Alasan memilih negara Malaysia sebagai sampel karena Malaysia merupakan negara yang masih serumpun dengan Indonesia, dan tingkat perekonomian yang masih sebanding. Selain itu negara Indonesia dan Malaysia termasuk negara berkembang. Malaysia juga merupakan bagian dari anggota Association of Southeast Asian Nation (ASEAN). 


\section{KERANGKA PEMIKIRAN TEORITIS DAN PENGEMBANGAN HIPOTESIS}

\section{Teori Legitimasi}

Teori legitimasi ini didasarkan atas kontrak sosial antara perusahaan dengan masyarakat. Teori ini mendasari masa depan organisasi bergantung pada apakah organisasi tersebut memberikan kesejahteraan kepada masyarakat atau tidak. Organisasi tersebut menjalankan operasionalnya, dimana perusahaan dalam menjalankan bisnisnya harus memperhatikan norma-norma yang berlaku di masyarakat (Deegan, 2002). Teori legitimasi didasarkan oleh persepsi, tetapi persepsi saja tidak cukup. Mereka harus melakukan tindakan bertanggung jawab sosial didukung dengan pengungkapan, mempublikasikan, dan melaporkan dalam laporan tahunan perusahaan (Magness, 2006).

Teori legitimasi menyebutkan bahwa legitimasi merupakan faktor penting bagi perusahaan dalam rangka mengembangkan perusahaan ke depan. Hal-hal yang berkaitan dengan etika bisnis, perhatian dan pengembangan kinerja karyawan, dampak terhadap lingkungan perusahaan turut berkontribusi dalam meningkatkan legitimasi. Dengan demikian maka kepedulian perusahaan terhadap lingkungan yang kemudian ditunjukkan melalui environmental disclosures, diharapkan dapat meningkatkan legitimasi dan berdampak baik untuk jangka panjang perusahaan.

\section{Teori Keagenan}

Teori keagenan menjelaskan hubungan antara prinsipal dan agen yang dilandasi dengan adanya pemisahan kepemilikan dan pengendalian perusahaan, pemisahan penanggung risiko, pembuatan keputusan dan pengendalian fungsi-fungsi (Jensen and Meckling, 1976). Menurut Brigham dan Daves (2010), hubungan keagenan muncul ketika satu orang atau lebih yang disebut prinsipal melimpahkan tanggung jawab ke individu lain atau organisasi yang disebut agen untuk melaksanakan pekerjaan serta pengambilan keputusan. Di sisi lain manajer memiliki tujuan pribadi yang bersaing dengan tujuan memaksimalkan kesejahteraan pemegang saham. Hal inilah yang menciptakan konflik potensial atas kepentingan yang disebut dengan teori agen (agency theory).

Manajer yang memiliki saham yang tinggi dalam suatu perusahaan akan lebih menyelaraskan kepentingannya dan kepentingan pemegang saham. Maka dari itu, ia akan bekerja lebih produktif untuk meningkatkan citra perusahaan demi keberlangsungan hidup perusahaan dan demi kesejahteraan pemegang saham. Hal ini mendorong manajer untuk memberikan informasi yang relevan terhadap stakeholders dalam jumlah yang lebih banyak dan lebih luas termasuk dalam pengungkapan informasi lingkungan. Dengan demikian perusahaan dapat memiliki citra yang baik di mata masyarakat atas pengelolaan yang baik terhadap lingkungan (Raharjo, 2007).

\section{Teori stakeholders}

Menurut Huang dan Kung (2017) teori stakeholders menyatakan suatu aktivitas yang dilakukan perusahaan yang dipengaruhi oleh kepentingan individu atau kelompok. Dalam teori stakeholders menyatakan tentang bagaimana pemegang saham dan manajer menciptakan nilai. Interaksi antara stakeholders dengan 
perusahaan merupakan hubungan timbal balik. Stakeholders menyediakan sumberdaya yang dibutuhkan perusahaan sedangkan perusahaan memenuhi tuntutan dari stakeholders. Teori ini berhubungan dengan environmental disclosures, jika dukungan stakeholders kuat terhadap aktivitas perusahaan maka, semakin tinggi pengungkapan sosial yang dilakukan perusahaan. Fatayaningrum (2011) mengungkapkan beberapa alasan pentingnya mengutamakan kepentingan stakeholders adalah :

\section{Isu lingkungan oleh pihak-pihak yang berkepentingan akan menganggu kehidupan masyarakat.}

Ketika mengeluarkan produknya perusahaan dituntut untuk memperhatikan aspek lingkungan akibat dari pengeluaran produk tersebut. Untuk menanamkan sahamnya para investor lebih memilih perusahaan yang memperhatikan aspek lingkungan dan pengungkapan sosial.

Stakeholders memiliki kepentingan dan pandangan yang berbeda, mengenai bagaimana menjalankan operasi perusahaan. Stakeholders menjalankan kontrak sosial dengan stakeholders lain yang memiliki kepentingan yang berbeda (Huang dan Kung, 2017). Menurut Donaldson dan Preston (1995), environmental disclosures dianggap menjadi cara bagi perusahaan untuk memberikan informasi mengenai aktivitas perusahaan bagi pemangku kepentingan lain.

\section{Pengaruh Kepemilikan Manajerial Terhadap Environmental Disclosures}

Environmental disclosures dinilai sebagai kebijakan yang dapat meningkatkan citra perusahaan. Citra perusahaan yang meningkat tentu akan berdampak positif pula terhadap kepentingan manajer sebagai pemegang saham. Maka dari itu, environmental disclosures dapat dijadikan sebagai cara manajer untuk menyelaraskan kepentingannya sebagai manajer dan sebagai pemegang saham (Oktafianti dan Rizki, 2015). Anggraini (2006) menemukan bahwa adanya pengaruh positif kepemilikan manajerial terhadap environmental disclosures. Hal ini karena semakin banyak kepemilikan manajemen di dalam perusahaan, manajemen akan semakin banyak melakukan kegiatan produktif yang dapat meningkatkan citra perusahaan.

Buniamin et al. (2010) di Malaysia kepemilikan manajerial tidak berpengaruh terhadap environmental disclosures. Kepemilikan manajerial yang lebih rendah akan menghasilkan kecenderungan yang lebih besar untuk pelaporan lingkungan. Hal ini karena pelaporan lingkungan adalah bersifat sukarela, perusahaan tidak merasakan tekanan untuk melakukannya.Tarmizi (2012) menemukan terdapat pengaruh positif kepemilikan manajerial terhadap environmental disclosures. Manajemen yang memiliki saham perusahaan tentunya akan menyelaraskan kepentingannya dengan kepentingan sebagai pemegang saham. Oleh karena itu, semakin besar kepemilikan manajer di dalam perusahaan, manajer perusahaan akan semakin banyak mengungkapkan informasi sosial.

Oktafianti dan Rizki (2015) menemukan adanya pengaruh positif kepemilikan manajerial terhadap environmental disclosures. Kepemilikan manajer yang semakin besar membuat manajer lebih memikirkan kepentingan dan kesejahteraan pemegang saham. Kinerjanya semakin produktif demi keberlangsungan perusahaan dan kesejahteraan pemegang saham, sehingga manajer akan memberikan informasi yang relevan bagi stakeholdersyang lebih luas. Manajemen yang memiliki saham perusahaan tentunya akan menyelaraskan 
kepentingannya dengan kepentingan sebagai pemegang saham sehingga semakin besar kepemilikan manajer di dalam perusahaan, manajer perusahaan akan semakin banyak mengungkapkan informasi sosial. Selain itu pernyataan dari Fama dan Jensen (1983), jika kepemilikan manajerial dalam suatu perusahaan tinggi, maka manajemen cenderung untuk melakukan environmental disclosures. Berdasarkan uraian di atas, maka dapat dirumuskan hipotesis :

$\mathbf{H}_{1 \mathrm{a}}$ : Kepemilikan manajerial berpengaruh positif terhadap environmentaldisclosures di Indonesia. $H_{1 b}$ : Kepemilikan manajerial berpengaruh positif terhadap environmental disclosures di Malaysia.

\section{Pengaruh Ukuran Dewan Komisaris TerhadapEnvironmental Disclosures}

Arta dan Sari (2015) menemukan bahwa ukuran dewan komisaris memiliki pengaruh positif terhadap luas pengungkapan lingkungan. Hal ini karena semakin besar jumlah anggota dewan komisaris, maka akan semakin mudah untuk mengendalikan Chief Executives Officer (CEO) dan monitoring yang dilakukan semakin efektif. Maka dari itu, tekanan yang diberikan dalam melakukan pengungkapan informasi lingkungan semakin besar. Penelitian dari Malaysia Haniffa dan Cooke (2002) menemukan bahwa ukuran dewan komisaris tidak berpengaruh terhadap environmental disclosures. Seberapa banyaknya jumlah dewan komisaris perusahaan tidak akan seluruhnya akan memberikan perhatian terhadap pengungkapan lingkungan, sehingga dewan komisaris tidak ada urusan atau kepentingan terkait dengan pengungkapan lingkungan. Hasil penelitian dari Frendy dan Kusuma (2011) menemukan bahwa ukuran dewan komisaris memiliki pengaruh positif terhadap environmental disclosures.

Htay (2012a) menemukan ukuran dewan komisaris di Malaysia berpengaruh positif terhadap environmental disclosures, karena dengan jumlah dewan komisaris yang lebih banyak maka hubungan dengan organisasi dan direksi di luar perusahaan juga akan banyak maka perusahaan akan memberikan sumber informasi terkait dengan environmental disclosures. Perusahaan yang memiliki ukuran dewan komisaris yang lebih banyak maka akan memiliki fungsi pengawasan yang kuat sehingga aktivitas bisnis yang dilakukan perusahaan akan lebih transaparan dalam memberikan informasi bagi stakeholders maupun shareholders. Selain itu bagi pihak manajemen dapat meningkatkan fungsi pengawasan yang semakin kuat. Tekanan yang dihadapi akan semakin kuat sehingga dapat terdorong untuk melakukan environmental disclosures (Sembiring, 2005). Berdasarkan uraian di atas, maka dapat dirumuskan hipotesis :

\section{$\mathrm{H}_{2 \mathrm{a}}$ : Ukuran dewan komisaris berpengaruh positif terhadap environmental disclosures di Indonesia.} $\mathbf{H}_{2 b}$ : Ukuran dewan komisaris berpengaruh positif terhadap environmental disclosures di Malaysia.

\section{Pengaruh Ukuran Perusahaan Terhadap Environmental Disclosures}

Menurut Suryono dan Prastiwi (2011), perusahaan yang lebih besar akan memiliki aktivitas dalam rangka menyejahterakan masyarakat. Pemegang saham kemudian akan memperhatikan laporan keuangan terkait dengan aktivitas yang diinformasikan oleh pemegang saham. Ukuran perusahaan yang semakin besar maka pengungkapan informasi mengenai aktivitas perusahaan akan semakin luas pula, hal ini bertujuan menginformasikan kepada stakeholders tekait dengan tujuan dan kinerja yang akan dicapai, mengalihkan 
isu-isu penting yang lain, dan mengubah ekspektasi eksternal yang berhubungan dengan kinerja organisasi (Sembiring, 2003).

Agusti (2010) dan Sembiring (2005) menemukan bahwa ukuran perusahaan memiliki pengaruh positif terhadap environmental disclosures. Hal ini karena perusahaan besar merupakan emiten yang paling banyak disoroti oleh publik sehingga pengungkapan yang lebih besar merupakan pengurangan biaya politis sebagai wujud tanggung jawab perusahaan. Suhardjanto dan Miranti (2009) menemukan bahwa ukuran perusahaan tidak berpengaruh terhadap environmental disclosures. Oktafianti dan Rizki (2015) menemukan bahwa ukuran perusahaan berpengaruh positif terhadap environmental disclosures. Penelitian di Malaysia Smith et al. (2007) serta Buniamin (2010) hasilnya bahwa ukuran perusahaan berpengaruh positif terhadap environmental disclosures.

Pengungkapan yang dilakukan perusahaan besar cenderung lebih tinggi dibandingkan perusahaan kecil sebagai wujud tanggung jawab perusahaan atas dampak lingkungan yang diakibatkan oleh aktivitas eksplorasi, eksploitasi dan produksi. Perusahaan besar juga mengalami tekanan sosial dan politik yang lebih tinggi dibandingkan dengan perusahaan kecil karena aktivitas yang dilakukan oleh perusahaan besar lebih disoroti oleh stakeholders (Patten, 1991). Maka dari itu, sebagai bentuk tanggungjawab terhadap pemegang saham, perusahaan yang memiliki ukuran besar akan cenderung melakukan environmental disclosures yang lebih luas. Berdasarkan uraian di atas, maka dapat dirumuskan hipotesis :

\section{$\mathrm{H}_{3 \mathrm{a}}$ : Ukuran perusahaan berpengaruh positif terhadap environmental disclosures di Indonesia. $H_{3 b}$ : Ukuran perusahaan berpengaruh positif terhadap environmental disclosures di Malaysia.}

\section{Pengaruh Likuiditas Terhadap Environmental Disclosures}

Perusahaan yang memiliki rasio likuiditas tinggi artinya memiliki jumlah aset lancar yang lebih besar daripada hutang lancar. Hal ini merupakan sinyal positif bagi para stakeholders bahwa perusahaan dalam kondisi baik. Pada umumnya perusahaan yang memiliki likuiditas yang baik akan memperkuat sinyal positif perusahaan kepada stakeholders dengan melakukan pengungkapan informasi tambahan termasuk environmental disclosures. Syahrir dan Suhendra (2010) menemukan bahwa likuiditas berpengaruh positif terhadap CSR disclosures. Penelitian ini akan menguji pengaruh likuiditas terhadap environmental disclosures.

Perusahaan dengan likuiditas yang tinggi akan memberikan sinyal kepada perusahaan yang lain bahwa mereka lebih baik daripada perusahaan lain dengan melakukan kegiatan yang berhubungan dengan lingkungan. Maka dari itu, perusahaan terdorong untuk melakukan pengungkapan lingkungan. Penelitian yang dilakukan oleh Kamil dan Herusetya (2012) menunjukkan bahwa likuiditas tidak berpengaruh terhadap voluntary disclosures dalam hal ini adalah CSR disclosures. Hal ini karena kurangnya perhatian stakeholders yang berkepentingan terhadap informasi keuangan, kurangnya memperhitungkan kualitas likuiditas entitas maka akhirnya tidak banyak memengaruhi luas pengungkapan sukarela yaitu CSR disclosures.

Daniel (2013) menemukan bahwa likuiditas berpengaruh positif terhadap luas pengungkapan laporan keuangan. Hal ini bahwa tingkat likuiditas yang tinggi akan menunjukkan kuatnya kondisi keuangan perusahaan. Perusahaan semacam ini cenderung untuk melakukan pengungkapan informasi yang lebih luas 
kepada pihak luar karena ingin menunjukkan bahwa perusahaan tersebut kredibel. Tingkat likuiditas mempunyai hubungan positif dengan luas pengungkapan. Kondisi perusahaan sehat dapat ditunjukkan dari tingkat likuiditas yang berhubungan dengan tingkat pengungkapan yang lebih. Hal ini didasarkan pada harapan bahwa kekuatan financial perusahaan akan cenderung memberikan pengungkapan yang lebih untuk memberikan informasi yang luas dari pada perusahaan dengan kondisi financial lemah (Benardi et al.,2009). Iswandika et al. (2014), perusahaan dengan likuiditas yang tinggi akan memberikan sinyal bahwa mereka lebih baik daripada perusahaan lain. Sinyal ini ditunjukkan dengan melakukan berbagai aktivitas yang tanggung jawab sosial dan lingkungan. Kegiatan-kegiatan yang berkaitan dengan lingkungan ini kemudian diungkapkan dalam laporan tahunan sebagai environmental disclosures. Maka, dapat diasumsikan bahwa likuiditas perusahaan berpengaruh positif terhadap environmental disclosures perusahaan. Berdasarkan uraian di atas, maka dapat dirumuskan hipotesis:

\section{$H_{4 a}$ : Likuiditas berpengaruh positif terhadap environmental disclosures di Indonesia. $\mathbf{H}_{4 b}$ : Likuiditas berpengaruh positif terhadap environmental disclosures di Malaysia.}

\section{Perbedaan Tingkat Environmental Disclosures di Indonesia dan Malaysia}

Dewasa ini, kerusakan lingkungan hidup akibat aktivitas perusahaan semakin marak terjadi. Hal ini tidak hanya terjadi di Indonesia, melainkan juga terjadi di seluruh penjuru dunia. Negara-negara maju umumnya memiliki sistem hukum yang tegas untuk meminimalisir hal tersebut. Negara-negara berkembang seperti Indonesia dan Malaysia pun mulai meningkatkan upaya mereka dalam mengurangi kerusakan lingkungan hidup yang diakibatkan oleh aktivitas perusahaan.Indonesia dan Malaysia merupakan negara berkembang yang berada di wilayah yang sama yakni Asia Tenggara di mana telah diberlakukan ASEAN Economic Community. Diberlakukannya ASEAN Economic Community bertujuan untuk meningkatkan perekonomian negara-negara di Asia Tenggara. Besarnya harapan dan upaya untuk memajukan perekonomian harus diimbangi dengan peningkatan tanggung jawab terhadap lingkungan hidup. Apabila tidak diimbangi dengan peningkatan tanggung jawab terhadap lingkungan hidup, maka akan sangat berpotensi menimbulkan kerusakan lingkungan hidup (Putri, 2014). Maka dari itu, selain masalah ekonomi, masalah tanggung jawab terhadap lingkungan hidup di kedua negara tersebut juga sangat penting untuk diperhatikan. Environmental disclosures sebagai tanggungjawab dalam pengungkapan lingkungan seharusnya sudah menjadi kewajiban bagi perusahaan setelah melakukan kegiatan operasinya. Sebab, masalah pencemaran lingkungan sudah serius dan harus segera diatasi oleh perusahaan untuk dapat mendapatkan kepercayaan kembali dari masyarakat (Putri, 2015)

Realitanya, masih banyak perusahaan Indonesia dan Malaysia yang kurang memperhatikan kelestarian lingkungan hidup. Pencemaran sungai dan kebakaran hutan di berbagai daerah di Sumatera, Kalimantan, dan Papua merupakan salah satu bukti bahwa kerusakan lingkungan akibat aktivitas perusahaan di Indonesia masih cukup tinggi (Greenpeace, 2016). Secara tidak langsung hal ini juga menunjukkan bahwa penerapan environmental disclosures di Indonesia masih membutuhkan perbaikan. Hal ini tidak hanya terjadi di Indonesia, melainkan juga di Malaysia. Hasil penelitian yang dilakukan oleh Buniamin et al.(2011) menujukkan bahwa 
pelaporan lingkungan di Malaysia masih rendah, maka perlu adanya perbaikan.Walaupun sama-sama membutuhkan perbaikan, namun tingkat environmental disclosures di setiap negara pasti berbeda-beda. Kondisi sumber daya alam, ekonomi, dan perbedaan permasalahan lingkungan dan sosial yang berkembang di kedua negara bisa jadi alasan untuk menyatakan bahwa penerapan environmental disclosures di Indonesia dan Malaysia berbeda. Asumsi ini sejalan dengan hasil penelitian yang dilakukan oleh Putri (2015) yang menyatakan bahwa terdapat perbedaaan tingkat environmental disclosures di Indonesia, Malaysia dan Thailand. Berdasarkan uraian di atas, maka dapat dirumuskan hipotesis:

\section{$\mathrm{H}_{5}$ :Terdapat perbedaan tingkat environmental disclosures di Indonesia dan Malaysia.}

\section{METODE PENELITIAN}

\section{Populasi dan Tenik Sampel}

Penelitian ini menggunakan populasi seluruh perusahaan yang terdaftar di Bursa Efek Indonesia dan Bursa Malaysia. Periode penelitian mencakup data tahun 2016, hal ini bertujuan untuk menggunakan data yang terbaru. Sampel dalam penelitian ini menggunakan perusahaan dibidang manufaktur. Perusahaan manufaktur lebih luas dalam pengungkapan lingkungan dan memiliki dampak yang cukup besar terkait dengan pencemaran lingkungan akibat limbah pabrik yang dihasilkan.Penelitian ini menggunakan teknik pengambilan dengan menggunakan metode purposive sampling. Metode purposive sampling adalah pemilihan sampel tidak secara acak, namun menggunakan kriteria-kriteria tertentu yang ditetapkan oleh peneliti. Dalam penelitian ini pengambilan sampel dengan menggunakan kriteria sebagai berikut :

- Perusahaan sektor manufaktur yang menerbitkan laporan tahunan perusahaan (annual report) yang terdaftar di Bursa Efek Indonesia dan Bursa Malaysia tahun 2016.

- Perusahaan yang menerbitkan laporan tahunan secara lengkap.

- Perusahaan yang menerbitkan laporan tahunan yang memiliki data lengkap terkait semua variabel penelitian.

\section{Jenis dan Teknik Pengumpulan Data}

Penelitian ini termasuk dalam penelitian kuantitatif yaitu jenis data sekunder. Pengambilan data diperoleh dari annual report perusahaan manufaktur yang terdaftar di Bursa Efek Indonesia dan Bursa Malaysia pada tahun 2016.Teknik pengumpulan data pada penelitian ini dilakukan dengan cara dokumentasi atau sering disebut data sekunder, yaitu teknik pengumpulan data yang berasal dari pencatatan sumber data atau publikasi lain. Data diperoleh dari laporan tahunan dan summary of financial statement perusahaan yang menjadi sampel penelitian. Sumber publikasi dengan cara mengunduh laporan tahunan perusahaan manufaktur pada tahun 2016 yang diakses melalui www.idx.com dan www.bursamalaysia.com

\section{Environmental Disclosures}

Environmental disclosures adalah kontribusi perusahaan dalam menginformasikan aktivitas-aktivitas lingkungan yang dilaksanakan oleh perusahaan. Aktivitas lingkungan tersebut dilaporkan melalui laporan 
tahunan perusahaan yang berguna untuk pihak yang berkepentingan (Brown dan Deegan, 1998). Pengukuran yang digunakan dalam environmental disclosure adalah menggunakan checklist dengan berpedoman pada Global Reporting Initiative (GRI). Terdapat 34 indikator yang direkomendasikan oleh GRI G4 yang merupakan penjabaran dari 12 aspek. Adapun 12 aspek tersebut adalah bahan baku, energi, air, keanekaragaman hayati, emisi, effluent dan limbah, produk dan jasa, kepatuhan, transportasi, lain-lain, asessment pemasok atas lingkungan dan mekanisme pengaduan masalah lingkungan (Effendi et al.,2011).

\section{Kepemilikan Manajerial}

Kepemilikan manajerial menunjukkan seberapa besar proporsi saham yang dimiliki oleh manajemen dalam suatu perusahaan. Kepemilikan manajerial tersebut dapat dilihat pada laporan keuangan yang diterbitkan oleh perusahaan. Pengukuran kepemilikan manajerial menggunakan rumus sebagai berikut (Jensen and Meckling, 1976 ) :

$$
\text { kepemilkan manajerial }=\frac{\text { Jumlah Saham Dewan Direksi }}{\text { Total Saham yang Beredar }} \times 100 \%
$$

\section{Ukuran Dewan Komisaris}

Ukuran dewan komisaris adalah banyaknya anggota dewan komisaris yang menjadi anggota di perusahaan. Jumlah anggota dewan komisaris diukur dengan jumlah komisaris dari pihak yang terafiliasi (memiliki hubungan, salah satunya pihak internal perusahaan) dan tidak terafiliasi (tidak memiliki hubungan) dengan perusahaan (KNKG, 2006). Pengukuran ukuran dewan komisaris menggunakan proksi:

$$
U D K=\text { Total Anggota Dewan Komisari }
$$

\section{Ukuran Perusahaan}

Ukuran perusahaan menunjukkan besar kecilnya suatu perusahaan yang dapat diukur melalui kapitalisasi pasar, total modal, total aktiva serta total penjualan. Perhitungan ukuran perusahaan mengacu pada penelitian yang dilakukan oleh Oktafianti dan Rizki (2015) diproksikan sebagai berikut :

$$
\text { size }(t)=\operatorname{Ln}(\text { total aktiva pada periode ke } t)
$$

\section{Likuiditas}

Likuiditas adalah ukuran yang dapat digunakan untuk mengukur kemampuan perusahaan dalam memenuhi atau melunasi hutang-hutang jangka pendek. Likuiditas dalam penelitian ini akandiukur menggunakan rasio lancar atau current ratio. Rumus perhitungan likuiditas mengacu pada penelitian Daniel (2013). Pengukuran likuiditas menggunakan rumus sebagai berikut :

$$
\text { Current Ratio : } \frac{\text { Aktiva Lancar }}{\text { Kewajiban Lancar }}
$$




\section{Analisis Data}

\section{Statistik Deskriptif}

Statistik deskriptif ini digunakan untuk menjelaskan tentang mean, maksimum,variance, range, standar deviasi, minimum dan jumlah data yang digunakan dalam penelitian ini. Mean merupakan nilai rata-rata data yang terdapat dalam penelitian. Maksimum merupakan nilai terbesar dari jumlah nilai yang terdapat dalam penelitian. Minimum adalah nilai terkecil yang ditemukan dalam penelitian. Standar deviasi dapat dijadikan sebagai penentu jenis data yang sering terjadi dalam penelitian.

\section{Uji Asumsi Klasik}

Uji asumsi klasik merupakan prosedur berikutnya yang harus dilakukan supaya hasil analisis data pada penelitian ini memenuhi syarat pengujian. Tujuan dari uji asumsi klasik adalah untuk mengetahui apakah hasil dari regresi berganda terjadi penyimpangan dari asumsi klasik. Uji yang dilakukan meliputi uji normalitas, multikolinearitas, dan heteroskidastisitas (Ghozali, 2011)

\section{Uji Hipotesis}

Metode analisis data merupakan suatu teknik atau prosedur untukmenguji hipotesis penelitian. Metode ini menggunakan pengujian seperti analisis statistik deskriptif, uji koefisien determinasi, dan uji hipotesis. Dalam melakukan pengujian pengaruh variabel bebas terhadap variabel terikat, penelitian ini menggunakan analisis regresi berganda (multiple regression analysis). Persamaan regresi berganda adalah :

$$
E D=\alpha_{0}+\beta_{1} K M+\beta_{2} U D K+\beta_{3} S I Z E+\beta_{5} C R+e
$$

Keterangan :

$$
\begin{array}{ll}
E D & =\text { Environmental Disclosures } \\
\alpha_{0} & =\text { Konstanta } \\
\beta_{1} K M & =\text { Kepemilikan Manajerial } \\
\beta_{2} U D K & =\text { Ukuran Dewan Komisaris } \\
\beta_{3} S I Z E & =\text { Ukuran Perusahaan } \\
\beta_{5} C R & =\text { Likuiditas } \\
e & =\text { errorterm }
\end{array}
$$

\section{Uji Signifikansi Parameter Individual (uji nilai t)}

Uji signifikansi parameter individual (Uji t) digunakan untuk menguji hipotesis pengaruh variabel independen terhadap variabel dependen secara parsial. Terkait dengan penelitian ini, uji t digunakan untuk menguji hipotesis satu $\left(\mathrm{H}_{1}\right)$ sampai dengan hipotesis enam $\left(\mathrm{H}_{4}\right)$ dengan menggunakan model penelitian pertama. Hipotesis dinyatakan diterima apabila nilai sig < a $(0,05)$ dan koefisien regresi searah dengan hipotesis. 


\section{Uji Beda (Independent Sample t test)}

Pengujian independent sample t test dilakukan untuk mengetahui perbedaan penerapan environmental disclosures di Indonesia dan Malaysia. Uji ini dilakukan untukmenguji hipetsis ketujuh $\left(\mathrm{H}_{5}\right)$ dengan menggunakan model penelitian kedua. Sebelum melakukan uji t, sebelumnya dilakukan uji kesamaan varian (homogenitas) dengan $\mathrm{F}$ test (levene test). Jika variannya sama, maka uji t menggunakan Equal Variance Assumed (diasumsikan varian sama). Jika variannya berbeda, maka menggunakan equal variance not assumed (diasumsikan varian berbeda). Hipotesis alternatif diterima jika nilai sig $<0,05$ dan jika nilai sig $>0,05$ maka hipotesis alternatif ditolak.

\section{HASIL PENELITIAN DAN PEMBAHASAN}

\section{Gambaran Umun Objek Penelitian}

Objek Penelitian ini adalah perusahaan manufaktur yang terdaftar di Bursa Efek Indonesia (BEI) dan Bursa Malaysia pada tahun 2016. Metode pemilihan sampel menggunakan metode purposive sampling dengan kriteria yang telah dijelaskan di bab sebelumnya. Berdasarkan metode purposive sampling perusahaan yang memenuhi kriteria adalah berjumlah 59 perusahaan manufaktur di Indonesia dan 63 perusahaan manufaktur di Malaysia. Pada Tabel 1 disajikan statistik deskriptif dari data penelitian di dua Negara tersebut.

\section{Uji Asumsi Klasik}

Sebelum dilakukan uji hipotesis dengan analisis regresi, terlebi dahulu dilakukan uji kualitas dataatau yang sering disebut uji asumsi klasik yang terdiri dari pengujian normalitas, multikolinearitas, dan heteroskedastisitas, baik untuk untuk Indonesia maupun Malaysia. Dari hasil analisis dengan menggunakan software SPSS, diketahuinilai sig. pada uji kolmogorov smirnovlebih dari 0,05, Variance Inflation Factor (VIF) lebih dari 0,10, dan uji heteroskedastisitas menghasilkan nilai sig lebih dari 0,05. Dengan demikian maka dapat disimpulkan bahwa tidak ada masalah asumsi klasik pada data penelitian baik untuk Indonesia maupun Malaysia.

\section{Uji Hipotesis}

Uji hipotesis dilakukan dengan dua teknik, yakni analisis regresi untuk $\mathrm{H}_{1}$ sampai $\mathrm{H}_{4}$ dan uji beda untuk $\mathrm{H}_{5}$ Uji hipotesis untuk data Indonesia di sajikan pada Tabel 3 untuk Indonesia dan Tabel 4 untuk Malaysia. Dari hasil pengujian di Indonesia, hanya Ukuran Dewan Komisaris yang berpengaruh terhadap environmental disclosures. Adapaun di Malaysia, ada tiga faktor yang mempengaruhi environmental disclosures, yakni Kepemilikan Manajerial, Ukuran Perusahaan, dan Tingkat Likuiditas Perusahaan.

\section{Uji Beda (Independent Sample T Test)}

Uji beda bertujuan untuk mengetahui perbedaan environmental disclosures di Indonesia dan Malaysia. Hasil uji beda penelitian ini disajikan pada Tabel 5 dan 6. Pada tabel 5 dapat disimak jumlah perusahaan Indonesia adalah 59 perusahaan dan Malaysia adalah 63 perusahaan. Rata-rata environmental disclosures di 
Indonesia sebesar 0,0686 dan di Malaysia sebesar 0,0605.

Berdasarkan Tabel 6 didapatkan hasil bahwa nilai $\mathrm{F}$ hasil Levene's test for equality of variance assumed sebesar 163,410 dengan signifikan 0,037 karena signifikan < 0.05 maka dapat disimpulkan bahwa kedua negara tersebut (Indonesia dan Malaysia) memiliki perbedaan environmental disclosures. Dengan demikian hipotesis kelima $\left(\mathrm{H}_{5}\right)$ yang menyatakan bahwa terdapat perbedaan tingkat environmental disclosures antara Indonesia dan Malaysia dinyatakan diterima.

\section{Pembahasan}

Hasil pengujian hipotesis ke satu $\left(\mathrm{H}_{1 \mathrm{a}}\right)$ ditolak atau kepemilikan manajerial berpengaruh negatif terhadap environmental disclosures untuk sampel Indonesia. Environmental disclosures merupakan bagian dari corporate social responsibility disclosures dan Henderson (2001) menyatakan bahwa bagi pihak manajemen perusahaan, corporate social responsibility merupakan beban tambahan bagi manajemen dan tidak mendukung tugas pokoknya. Ada kemungkinan bahwa hal ini merupakan dasar mengapa hasil pengujian di Indonesia justru menunjukkan bahwa kepemilikan manajerial berpengaruh negatif terhadap environmental disclosures. Selain itu, aktivitas kepedulian lingkungan yang kemudian diungkapkan dalam environmental disclosures merupakan kebijakan yang membutuhkan biaya yang tidak sedikit. Hal ini akan menurunkan laba sekarang perusahaan, sedangkan timbal balik yang akan didapatkan perusahaan atas kebijakan tersebut tidak bisa dipastikan dan diukur.

Hasil pengujian hipotesis ke satu $\left(\mathrm{H}_{1 \mathrm{~b}}\right)$ diterima atau kepemilikan manajerial berpengaruh positif terhadap environmental disclosures untuk sampel Malaysia. Hal ini menunjukkan bahwa jajaran manajerial yang memiliki saham di perusahaan akan senantiasa mengupayakan kebijakan yang dinilai akan berdampak positif bagi perusahaan yang pada akhirnya juga akan memberikan dampak positif bagi dirinya selaku pemegang saham. Environmental disclosures dinilai sebagai kebijakan yang dapat memberikan citra positif bagi perusahaan yang pada akhirnya akan berpengaruh pada peningkatan laba perusahaan yang dan meningkatkan kesejahteraan pemegang saham (Anggraini, 2006)

Hasil penelitian ini konsisten dengan hasil penelitian yang dilakukan oleh Tarmizi (2012) serta Oktafianti dan Rizki (2015) yang hasilnya menunjukkan bahwa kepemilikan manajerial berpengaruh positif terhadap environmental disclosures. Kepemilikan manajer yang semakin besar membuat manajer lebih memikirkan kepentingan dan kesejahteraan pemegang saham. Kinerjanya semakin produktif demi keberlangsungan perusahaan dan kesejahteraan pemegang saham, sehingga manajer akan memberikan informasi yang relevan bagi stakeholders yang lebih luas. (Oktafianti dan Rizki, 2015)

Hasil pengujian hipotesis ke dua $\left(\mathrm{H}_{2 \mathrm{a}}\right)$ diterima atau ukuran dewan komisaris berpengaruh positif terhadap environmental disclosures untuk sampel Indonesia. Hasil penelitian ini sesuai dengan hasil penelitian sebelumnya yang dilakukan oleh Frendy dan Kusuma (2011) serta Sun et al (2010) menemukan terdapat pengaruh positif antara ukuran dewan komisaris dengan environmental disclosures. Hasil penelitian Htay (2012b) menemukan ukuran dewan komisaris di Malaysia berpengaruh positif terhadap environmental disclosures, karena dengan jumlah dewan komisaris yang lebih banyak maka hubungan dengan organisasi 
dan direksi di luar perusahaan juga akan banyak maka perusahaan akan memberikan sumber informasi terkait dengan environmental disclosures.

Berpengaruhnya variabel ukuran dewan komisaris dalam penelitian mengindikasikan dengan semakin banyaknya pengawasan terhadap aktivitas perusahaan akan membuat perusahaan menjadi lebih tertib dalam pengungkapan. Hal ini juga ditunjang dengan semakin banyaknya evaluasi setiap kebijakan dewan direksi baik yang akan dilaksanakan ataupun yang akan dikeluarkan. tugas dan tanggung jawab dari dewan komisaris adalah melakukan pengawasan dan memastikan bahwa perusahaan melaksanakan Good Corporate Governance sesuai aturan serta mengkoordinasikan kegiatan dewan komisaris agar pelaksanaan tugas dewan komisaris dapat berjalan efektif.

Hasil penelitian ini berhasil mendukung teori legitimasi, dimana menurut teori legitimasi, perusahaan mempunyai ikatan kontrak dengan masyarakat. Teori legitimasi menjelaskan bahwa pengungkapan tanggung jawab sosial akan dilakukan perusahaan dalam upaya untuk mendapatkan legitimasi dari masyarakat sekitar dan selanjutnya akan mengamankan perusahaan dari hal-hal yang dapat merugikan perusahaan. Oleh karena itu dewan komisaris ertanggung jawab untuk mengawasi manajemen akan senantiasa menyelaraskan nilai perusahaan kepada nilai masyarakat agar tidak membuat perusahaan kehilangan legitimasinya.

Hasil pengujian hipotesis ke dua $\left(\mathrm{H}_{2 b}\right)$ ditolak atau ukuran dewan komisaris tidak berpengaruh terhadap environmental disclosures untuk sampel Malaysia. Hasil penelitian ini sesuai dengan penelitian dari Malaysia Haniffa dan Cooke (2005) menemukan bahwa ukuran dewan komisaris tidak berpengaruh terhadap environmental disclosures. Seberapa banyaknya jumlah dewan komisaris perusahaan tidak akan seluruhnya akan memberikan perhatian terhadap pengungkapan lingkungan, sehingga dewan komisaris tidak ada urusan atau kepentingan terkait dengan pengungkapan lingkungan.

Tidak berpengaruhnya variabel ukuran dewan komisaris dalam penelitian dugaan dari peneliti hal ini dikarenakan tidak adanya kepentingan pasti dari dewan komisaris yang berhubungan dengan pengungkapan lingkungan, dengan demikian semakin banyaknya jumlah dewan komisaris tidak berarti apapun disebabkan sedikitnya atau hanya segelintir saja yang memperhatikan aspek lingkungan.Sehingga dari banyaknya sampel perusahaan pada penelitian, tidak ditemukan satu pun perusahaan yang berfokus pada pengungkapan lingkungan atau environmental disclosures. Selain itu, jumlah dewan komisaris yang terlalu besar akan lebih sulit dalam proses pengambilan keputusan, banyaknya ide/fikiran masing-masing dewan komisaris akan membutuhkan waktu yang lebih lama untuk mengambil satu kesimpulan sehingga kinerja menjadi kurang efektif.

Hasil pengujian hipotesis ke empat $\left(\mathrm{H}_{3 \mathrm{a}}\right)$ ditolak atau ukuran perusahaan tidak berpengaruh terhadap environmental disclosures untuk sampel Indonesia. Hasil pengujian ini sama dengan hasil penelitian yang dilakukan Anggraini (2006) yang menyatakan bahwa pengungkapan sosial dan lingkungan yang dilakukan perusahaan tidak dipengaruhi oleh ukuran perusahaan. Suhardjanto dan Miranti (2009) juga menemukan bahwa ukuran perusahaan tidak berpengaruh terhadap environmental disclosures. Alasan yang bisa dijadikan dasar atas hasil pengujian ini adalah perusahaan besar belum tentu melakukan environmental disclosures yang luas apabila perusahaan tersebut tidak menganggap bahwa kebijakan environmental disclosures sebagai 
kebijakan yang menguntungkan karena environmental disclosures masih bersifat sukarela.

Hasil pengujian hipotesis ke empat $\left(\mathrm{H}_{3 \mathrm{~b}}\right)$ diterima atau ukuran perusahaan berpengaruh positif terhadap environmental disclosures untuk sampel Malaysia. Hal ini berarti semakin besar ukuran perusahaan, maka semakin luas pula environmental disclosures perusahaan. Penelitian ini sesuai dengan Solikhah dan Winarsih (2015) menemukan bahwa ukuran perusahaan berpengaruh positif terhadap environmental disclosures. Ukuran perusahaan yang besar maka akan berpengaruh besar terhadap aktivitas operasi perusahaan di masyarakat. Hal ini sangat dimungkinkan memiliki pemegang saham yang lebih memperhatikan program-program sosial dan lingkungan yang dibuat oleh perusahaan.

Agusti (2010) dan Sembiring (2005) menemukan bahwa ukuran perusahaan memiliki pengaruh positif terhadap environmental disclosures. Hal ini karena perusahaan besar merupakan emiten yang paling banyak disoroti oleh publik sehingga pengungkapan yang lebih besar merupakan pengurangan biaya politis sebagai wujud tanggung jawab perusahaan.Selain itu, Pengungkapan yang dilakukan perusahaan besar cenderung lebih tinggi dibandingkan perusahaan kecil sebagai wujud tanggung jawab perusahaan atas dampak lingkungan yang diakibatkan oleh aktivitas eksplorasi, eksploitasi dan produksi. Perusahaan besar juga mengalami tekanan sosial dan politik yang lebih tinggi dibandingkan dengan perusahaan kecil karena aktivitas yang dilakukan oleh perusahaan besar lebih disoroti oleh stakeholders (Patten, 1991).Maka dari itu, sebagai bentuk tanggung jawab terhadap pemegang saham, perusahaan yang memiliki ukuran besar akan cenderung melakukan environmental disclosures yang lebih luas.

Hasil pengujian hipotesis ke enam $\left(\mathrm{H}_{4 \mathrm{a}}\right)$ ditolak atau likuiditas berpengaruh negatif berpengaruh terhadap environmental disclosures untuk sampel Indonesia. Hasil penelitian ini sesuai dengan Maiyarni et al (2014) juga menunjukkan bahwa likuiditas berpengaruh negatif terhadap CSR disclosures. Pada dasarnya, perusahaan yang memiliki likuiditas yang tinggi dapat diasumsikan sebagai perusahaan yang sedang dalam kondisi baik. Hasil penelitian ini dapat diinterpretasikan bahwa perusahaan yang memiliki likuditas yang tinggi enggan melakukan environmental disclosures karena sudah merasa cukup puas dengan kinerja keuangannya dan merasa bahwa environmental disclosures tidak terlalu berpengaruh terhadap investor (Maiyarni et al.,2014).

Selain itu, environmental discolsures juga membutuhkan biaya yang tidak sedikit yang dinilai justru bisa menambah beban keuangan perusahaan. Berbeda halnya dengan perusahaan yang memiliki likuiditas yang rendah. Maiyarni et al. (2014) dalam penelitiannya menyatakan bahwa perusahaan yang memiliki likuiditas rendah justru merasa penting untuk melakukan pengungkapan CSR guna menarik minat investor. Mengingat bahwa environmental disclosures merupakan bagian dari CSR disclosures, maka perusahaan yang memiliki likuiditas rendah juga akan cenderung meningkatkan environmental disclosures sebagai upaya untuk memikat para investor.

Hasil pengujian hipotesis ke enam $\left(\mathrm{H}_{4 \mathrm{~b}}\right)$ diterima atau likuiditas berpengaruh positif terhadap environmental disclosures untuk sampel Malaysia. Hasil penelitian ini sesuai dengan Daniel (2013) menemukan bahwa likuiditas berpengaruh positif terhadap luas pengungkapan laporan keuangan. Hal ini bahwa tingkat likuiditas yang tinggi akan menunjukkan kuatnya kondisi keuangan perusahaan. Perusahaan semacam ini cendrung untuk melakukan pengungkapan informasi yang lebih luas kepada pihak luar karena ingin 
menunjukkan bahwa perusahaan tersebut kredibel. Tingkat likuiditas mempunyai hubungan positif dengan luas pengungkapan. Kondisi perusahaan sehat dapat ditunjukkan dari tingkat likuiditas yang berhubungan dengan tingkat pengungkapan yang lebih. Hal ini didasarkan pada harapan bahwa kekuatan financial perusahaan akan cenderung memberikan pengungkapan yang lebih untuk memberikan informasi yang luas daripada perusahaan dengan kondisi financial lemah (Benardi et al.,2009)

Hasil pengujian hipotesis ke enam $\left(\mathrm{H}_{5}\right)$ menunjukkan bahwa terdapat perbedaan tingkat environmental disclosures antara Indonesia dengan Malaysia. Hal ini artinya, Hipotesis ke tujuh $\left(\mathrm{H}_{5}\right)$ diterima. Penelitian ini membuktikan bahwa terdapat perbedaan environmental disclosures di Indonesia dan Malaysia. Hal ini dikarenakan di Indonesia dan Malaysia pada pengungkapan CSR keduanya menggunakan Global Reporting Initiatives (GRI) 4 dengan 9 aspek dan 34 item. Adapun sembilan aspek utama itu yakni: material, air, transportasi, keanekaragaman hayati, energi, emisi dan limbah, ketaatan pada peraturan, produk dan jasa, serta keseluruhan biaya yang dikeluarkan untuk menjaga kelestarian lingkungan hidup. Meskipun pada dasarnya menggunakan pedoman yang sama, akan tetapi terdapat peraturan tentang pengungkapan yang belum dilaksanakan dengan baik oleh beberapa perusahaan, hal ini dibuktikan dengan masih adanya pelanggaran. Selain itu, environmental disclosure masih dianggap kurang penting bagi perusahaan. Sebab, orientasi utama perusahaan tetaplah mencari laba sebanyak-banyaknya dan pengungkapan lingkungan menjadi terabaikan sehingga lebih mementingkan para stakeholders utamanya dalam hal perolehan laba perusahaan. Kondisi sumber daya alam, ekonomi, dan perbedaan permasalahan lingkungan dan sosial yang berkembang di kedua negara bisa jadi alasan untuk menyatakan bahwa penerapan environmental disclosures di Indonesia dan Malaysia berbeda.

Hasil penelitian ini sesuai penelitian yang dilakukan oleh Putri (2015) yang menyatakan bahwa terdapat perbedaaan tingkat environmental disclosures di Indonesia, Malaysia dan Thailand. Selain itu, terdapat perbedaan pengungkapan di Indonesia dan Malaysia apabila dilihat dari nilai rata-rata (mean) sebesar 0,0686 atau 6,86\% yang artinya rata-rata pengungkapan environmental disclosures di Indonesia. Berbeda halnya dengan tingkat pengungkapan lingkungan di Malaysia yang mana nilai rata-rata (mean) sebesar 0,0605 atau 6,05\% yang artinya rata-rata pengungkapan environmental disclosures di Indonesia lebih tinggi dibandingkan dengan environmental disclosures di Malaysia atau (6,86\% > 6,05\%). Maka dari itu artinya environmental disclosures di Malaysia masih rendah, hal ini sesuai dengan hasil penelitian yang dilakukan oleh Buniamin et al. (2011) menujukkan bahwa pelaporan lingkungan di Malaysia masih rendah, maka perlu adanya perbaikan. Selain itu, penyebab perbedaan environmental disclosures di Indonesia dan Malaysia berbeda karena keberagamanan perusahaan. Di Malaysia dan belum ada standarisasi mengenai pengungkapan lingkungan ini. Terlebih jumlah perusahaan manufaktur di Malaysia cukup banyak sehingga penerapan pengungkapan menjadi beragam (Putri,2015).

\section{SIMPULAN}

Perusahaan yang menjadi objek dalam penelitian ini adalah perusahaan manufaktur yang terdaftar di Bursa Efek Indonesia (BEI) dan Bursa Malaysia (BM) pada tahun 2016. Penelitian ini menggunakan metode purposive sampling, jumlah perusahaan yang memenuhi kriteria untuk dijadikan sebagai sampel penelitian 
adalah sejumlah 59 sampel perusahaan untuk Indonesia dan 63 sampel untuk Malaysia. Penelitian ini menggunakan Global Reporting Initiative's (GRI) G4 sebagai indikator environmental disclosures yang mana di dalamnya terdapat 34 item pengungkapan lingkungan. Berdasarkan analisis dan pengujian data dalam penelitian ini, dapat ditarik kesimpulan kepemilikan manajerial berpengaruh negatif terhadap environmental disclosures di Indonesia. Hal ini membuktikan, bagi pihak manajemen perusahaan, environmental disclosures merupakan beban tambahan bagi manajemen dan tidak mendukung tugas pokoknya. Kepemilikan manajerial berpengaruh positif terhadap environmental disclosures di Malaysia. Hal ini membuktikan bahwa kepemilikan manajerial yang besar maka semakin produktif kinerja manajer demi keberlangsungan perusahaan dan kesejahteraan pemegang saham, sehingga manajer akan memberikan informasi yang relevan bagi stakeholders yang lebih luas termasuk environmental disclosures.

Ukuran dewan komisaris berpengaruh positif terhadap environmental disclosures di Indonesia. Hal ini membuktikan bahwa semakin banyaknya pengawasan terhadap aktivitas perusahaan akan membuat perusahaan menjadi lebih tertib dalam pengungkapan. Ukuran dewan komisaris tidak berpengaruh terhadap environmental disclosures di Malaysia hal ini karena jumlah dewan komisaris yang terlalu besar akan lebih sulit dalam proses pengambilan keputusan, banyaknya ide/fikiran masing-masing dewan komisaris akan membutuhkan waktu yang lebih lama untuk mengambil satu kesimpulan sehingga kinerja menjadi kurang efektif yang berdampak pada aktifitas pengungkapan lingkungan. Selanjutnya, ukuran perusahaan tidak berpengaruh terhadap environmental disclosures di Indonesia. Hal ini karena perusahaan besar belum tentu melakukan environmental disclosures yang luas apabila perusahaan tersebut tidak menganggap bahwa kebijakan environmental disclosures sebagai kebijakan yang menguntungkan karena environmental disclosures masih bersifat sukarela. Ukuran perusahaan berpengaruh positif terhadapenvironmental disclosures di Malaysia. Hal ini membuktikan bahwa environmental disclosures dilakukan perusahaan besar cenderung lebih tinggi dibandingkan perusahaan kecil sebagai wujud tanggung jawab perusahaan atas dampak lingkungan yang diakibatkan oleh aktivitas eksplorasi, eksploitasi dan produksi.

Likuiditas berpengaruh negatif terhadap environmental disclosures di Indonesia. Hal ini karena perusahaan dengan likuditas yang tinggi enggan melakukan environmental disclosures karena sudah merasa cukup puas dengan kinerja keuangannya dan merasa bahwa environmental disclosures tidak terlalu berpengaruh terhadap investor. Likuiditas berpengaruh positif terhadap environmental disclosures di Malaysia. Hal ini mengindikasikan kondisi perusahaan sehat dapat ditunjukkan dari tingkat likuiditas yang berhubungan dengan tingkat pengungkapan yang lebih. Terakhir, terdapat perbedaan tingkat environmental disclosures di Indonesia dan Malaysia. Hal ini mengindikasikan bahwa adanya perbedaan kondisi sumber daya alam, ekonomi, dan perbedaan permasalahan lingkungan dan sosial yang berkembang di kedua negara.

Penelitian ini memiliki beberapa keterbatasan penelitian yang dengan keterbatasan tersebut dapat berpengaruh terhadap hasil penelitian. Keterbatasan-keterbatasan yang ada dalam penelitian ini adalah sebagai berikut:Pertama, pnelitian ini hanya menggunakan sampel sektor perusahaan manufaktur. Oleh karena itu hasil penelitian ini tidak terlalu bisa digeneralisir pada tipe perusahaan lain. Karenanya, penelitian selanjutnya disarankan memperluas objek penelitian, tidak hanya perusahaan manufaktur saja namun 
ditambah sektor yang lain terkait dengan aktivitas usahanya yang berdampak langsung dengan lingkungan hidup seperti pertambangan, perkebunan, dan pertanian.

Variabel mekanisme corporate governance yang digunakan hanya kepemilikan manajerial, ukuran dewan komisaris dan jumlah rapat dewan komisaris. Oleh karena itu banyak variabel yang tidak searah dengan hipotesis penelitian. Kemungkinan karena variabel mekanisme corporate governance masih kurang tepat. Penelitian selanjutnya disarankan menambah variabel yang lebih luas untuk mekanisme corporate governance lainnya, dengan proksi kualitas audit, kepemilikan institusional, kepemilikan saham asing, kepemilikan keluarga, proporsi dewan komisaris independen dan sebagainya. Terakhir, penelitian ini hanya menggunakan satu negara pembanding yaitu Malaysia. Hal ini berakibat pada item checklist GRI 34 (G4) sangat sedikit, kondisi ini akibat environmental disclosures di Malaysia tidak transparan. Penelitian selanjutnya dianjurkan untuk menambah negara pembanding, yaitu negara yang memiliki kondisi alam dan perekonomian yang relatif seimbang dengan Indonesia seperti Australia, Thailand, Filipina dan sebagainya. 


\section{DAFTAR PUSTAKA}

Agusti, Restu. 2010, "Pengaruh Econonomic Performance dan Political Visibility terhadapPengungkapan Corporate Social Responsibility", Jurnal Ekonomi Universitas Riau, Vol. 18 No. 2.

Anggraini, R.R., (2006), “Pengungkapan Informasi Sosial dan Faktor-Faktor yang Mempengaruhi Pengungkapan Informasi Sosial dalam Laporan Keuangan Tahunan (Studi Empiris pada Perusahaan-Perusahaan yang terdaftar Bursa EfekJakarta)", makalah dalam Simposium Nasional Akuntansi IX (Padang).

Arta A.S.,Sari N.R, dan Savitri E, (2015), “Faktor - Faktor Yang Mempengaruhi Luas Pengungkapan Informasi Lingkungan Perusahaan Berbasis Website (Studi Empiris Pada Industri Rawan Lingkungan Yang Terdaftar Di Bei Tahun 2013)", Simposium Nasional Akuntansi XVIII Lampung, 1-20.

Benardi, Meliana K, Sutrisno, dan prihat Assih, 2009, Faktor-faktor Yang Mempengaruhi Luas Pengungkapan dan Implikasinya terhadap Asimetri Informasi (Studi Pada Perusahaan- Perusahaan Sektor Manufaktur Yang Go public di BEI), Simposium Nasional Akuntansi XII, Palembang 4-6

Brigham, Eugene F and Phillip R. Daves, 2010, Intermediate Financial Management 10th Edition, South-Western Cengage Learning. USA.

Brown, Noel dan Deegan, C. 1998, "The Public Disclosure of Environmental Performance Information (A dual Test of Media Agenda Setting Theory and Legitimacy Theory)", Accounting and Business Research, Vol. 29 No.1 pp 21-41.

Buniamin, S. 2010, "The quantity and quality of environmental reporting in annual report of public listed companies in Malaysia", Issues in Social and Environmental Accounting, Vol 4 No.2,hal 115-135.

Daniel, N. U, (2013), "Pengaruh Ukuran Perusahaan, Leverage dan Likuiditas Terhadap Luas Pengungkapan Laporan Keuangan (Studi Empiris pada Perusahaan Manufaktur yang Terdaftar di Bursa Efek Indonesia)", Jurnal Akuntansi, Vol 1 No. 1.

Deegan, C, (2002), "Introduction The Legitimizing effect of social and environmental disclosures-a theoretical foundation", Accounting, Auditing \& Accountability Journal, Vol 15 No 3, Hal 282-311.

Donaldson, T., dan Preston, L. E, (1995), “The stakeholder theory of the corporation”, The Academy of Management Review, Vol 20 No. 1, 65-91.

Effendi, B., Uzliawati, L., dan Yulianto, A. S. (2011), "Pengaruh Dewan Komisaris Terhadap Environmental Disclosure pada Perusahaan Manufaktur yang listing di BEI Tahun 2008-2011", Jurnal Akuntansi, Serang:Universitas Sultan Ageng Tirtayasa, (1998), 1-25.

Ekowati, Prasetyono, dan Wulandari, 2014, “Pengaruh Profitabilitas, Likuiditas,

Growth, dan Media ExposureTerhadap Pengungkapan Tanggungjawab SosialPerusahaan" (Studi Pada Perusahaan Manufaktur yang Terdaftar di BEI Tahun 2010-2012), Simposium Nasional Akuntansi 17.

Fama, E. F., dan Jensen, M. C, (1983), "Separation of ownership and control",The Journal of Law and Economics, Vol 26 No. 2,hal 301.

Fatayaningrum, Desie. 2011,"Analisis Pengaruh Manajemen Laba Dan Mekanisme Corporate Governance Terhadap Corporate Environmental Disclosure (Studi Empiris pada Perusahaan yang Terdaftar di BEI 
Tahun 2008-2009)",Skripsi, Universitas Diponegoro.

Frendy, dan Kusuma, I. W, (2011), "The Impact of Financial, Non-Financial, and Corporate Governance Attributes on The Practice of Global Reporting Initiative (GRI) based environmental disclosure", Gadjah Mada International Journal of Business, Vol 13 No. 2, hal 143-159.

Ghozali, Imam, 2011, Aplikasi Analisis Multivariate Dengan Program SPSS, Edisi Keempat, Penerbit Universitas Diponegoro.

Haniffa, R.M. dan T.E. Cooke, 2005, The Impact of Culture and Governance on Corporate Social Reporting, Journal of Accounting and Public Policy, Vol: 24: 391-430.

Haniffa, R. M., dan Cooke, T. E, (2002), “Culture , Corporate Governance and Disclosure in Malaysian Corporations", Abacus, Vol 38 No.3,hal 317-349.

Henderson, David, Misguided Virtue, 2001, False notions of corporate social ～responsibility, New Zealand Business Roundtable.

Huang, A. C., dan Kung, F, (2017),"Drivers of Environmental Disclosure and Stakeholder Expectation : Evidence from Taiwan", Journal of Etika Bisnis, Vol 96 No.3, hal 435-451.

Htay, S. N. N., Ab Rashid, H. M., Adnan, M. A., dan Meera, A. K. M, (2012), "Impact of corporate governance on social and environmental information, disclosure of Malaysian listed banks: Panel data analysis", Asian Journal of Finance \& Accounting, Vol 4 No.1, Hal 1.

Htay, S. N. N., Aung, M. Z., Rashid, H. M. A., dan Adnan, M. A, (2012), The "impact of corporate governance on the voluntary accounting information disclosure in Malaysian listed banks", Global Review of Accounting and Finance, Vol 3 No.2,hal 128-142.

Ikatan Akuntan Indonesia, 2007, Standar Akuntansi Keuangan. Edisi 2007. Penerbit : Salemba Empat, Jakarta. Iswandika, Ryandi., Muranto dan Sipayung, Emma. 2014, “Pengaruh Kinerja Keuangan, Corporate Governance, dan Kualitas Audit terhadap Pengungkapan Corporate Social Responsibility", E-Jurnal Akuntansi Fakultas Ekonomi Universitas Trisakti, Vol. 1 No. 2, hal 1-18.

Jensen,M. C., dan Meckling, W.H, (1976), Theory of the Firm: Managerial. Journal of Financial Economics, Vol 3, 305-360.

Kamil, A., dan Herusetya, A, (2012)," Pengaruh Karakteristik Perusahaan Terhadap Luas Pengungkapan Kegiatan Corporate Social Responsibility". Media Riset Akuntansi, Vol 2 No.1.

Komite Nasional Kebijakan Governace (KNKG), 2006, Pedoman Umum GoodＣorporate Governance di Indonesia. Jakarta.

Magness, V, (2006), "Strategic posture, financial performance and environmental disclosure: An empirical test of legitimacy theory". Accounting, Auditing \& Accountability Journal, Vol 19 No.4,hal 540-563.

Maiyarni, Susfayetti, dan Erwati, 2014, “Pengaruh Profitabilitas, Ukuran Perusahaan, Likuiditas, Dan Leverage Terhadap Pengungkapan Corporate Social Responsibility", Jurnal Cakrawala Akuntansi. Vol. 6 No. 1,hal. 79-94

Mardiyatnolo, A., M.M., S. E., dan Setiawati, E, (2015), “Pengaruh Kepemilikan Manajerial, Kualitas Keuangan Terhadap Corporate Environmental Disclosure Sebagai Bentuk Tanggung Jawab Sosial Dalam Laporan 
Tahunan ( Studi Empiris pada Perusahaan Perusahaan Peserta Proper dan terdaftar di Bursa Efek Indonesia Tahun, (2010)", Jurnal Akuntansi. hal 220-227.

Nik Ahmad, N. N., \& Sulaiman, M, (2004), “Environmental disclosure in Malaysian annual reports: A legitimacy theory perspective". International Journal of Commerce and Management, Vol 14 No.1, hal 44-58.

Oktafianti, D., dan Rizki, A, (2015), “Pengaruh Kepemilikan Manajerial , Ukuran Perusahaan dan Kinerja Keuangan Terhadap Corporate Environmental Disclosure Sebagai Bentuk Tanggung Jawab Sosial dalam Laporan Tahunan ( Studi pada Perusahaan Peserta Proper 2011-2013 )", Simposium Nasional Akuntansi XVIII Lampung, 22.

Patten, Dennis. M, 1991," Exposure, Legitimacy, and Social Disclosure", Journal of Accounting and Public Policy, Vol. 10

Prasetianti, N, (2014), “Pengaruh Media Dan Struktur Corporate Governance Terhadap Kualitas Environmental Disclosure", skripsi, Fakultas Ekonomi dan Bisnis Universitas Diponegoro., 2-97.

Putri, R. A., dan Christiawan, Y. J, (2014), "Pengaruh Profitabilitas, Likuiditas, dan Leverage terhadap pengungkapan Corporate Social Responsibility". Business Accounting Review, Vol 2 No. 1, 2014.

Putri, Areka Pratiwi, 2015, “Pengaruh Karakteristik Perusahaan terhadap Environmental Disclosure On Company Website". Thesis, Universitas Sebelas Maret, Surakarta.

Raharjo, E. (2007), "Agency Theory Vs Stewardship Theory in the Accounting Perspective", Jurnal Fakultas Ekonomi, STIE Pelita Nusantara Semarang, 2 No 1, hal37-46.

Said, R., Omar, N., dan Nailah Abdullah, W, (2013), “Empirical investigations on boards, business characteristics, human capital and environmental reporting". Social Responsibility Journal, Vol 9 No. 4, hal 534-553.

Sembiring, Eddy Rismanda, 2005, "Karakteristik Perusahaan dan Pengungkapan Tanggungjawab Sosial: Studi Empiris pada Perusahaan yang Tercatat di Bursa Efek Jakarta", Kumpulan Makalah Simposium Nasional Akuntansi 8. Solo, Hal 379-395.

Sembiring, E. R. 2003, “Kinerja Keuangan, Political Visibility, Ketergantungan pada Hutang, dan Pengungkapan Tanggung Jawab Sosial Perusahaan". Simposium Nasional Akuntansi VI. Surabaya, (1), 16-17.

Smith, M., Yahya, K., dan Amiruddin, A. M, (2007), “Environmental Disclosure and Performance Reporting in Malaysia", Asian Review of Accounting, Vol 15 No.2, hal 185-199.

Solikhah, B dan Winarsih A.M, (2015), “Pengaruh Media, Sensitivitas Industri Dan Struktur Corporate Governance Terhadap Kualitas Environmental Disclosure (Studi Pada Perusahaan High Profile Di Bursa Efek Indonesia Periode 2011-2013)", Accounting Analysis Journal, Vol 4 No. 2.

Suhardjanto, D, 2010, “Corporate Governance, Karakteristik Perusahaan dan Environmental Disclosure”, Jurnal Akuntansi, Universitas Sebelas Maret,Surakarta, Vol 6 No. 1.

Suhardjanto, D., dan Permatasari, N. D, (2010), “Pengaruh Corporate Governance, Etnis, dan Latar Belakang Pendidikan terhadap Environmental Disclosure: Studi Empiris pada Perusahaan Listing di Bursa Efek Indonesia", Jurnal Akuntansi, Universitas Sebelas Maret, Surakarta.Vol 14 No. 2, hal 151-164.

Sun, N., Salama, A., Hussainey, K., dan Habbash, M. 2010, "Corporate Environmental Disclosure, Corporate 
Governance, and Earnings management".Managerial Auditing Journal, Vol.25 No.27 pp 679-700.

Suhardjanto, D., dan Miranti, L. (2009)."Indonesian Environmental Reporting Index dan Karakteristik Perusahaan". Jurnal Akuntansi dan Auditing Indonesia, Vol 13 No. 1.

Suratno, I.B., Darsono dan Mutmainah, S., 2006,"Pengaruh Environmental Performance terhadap Environmental Disclosure dan Economic Performance (Studi Empiris pada Perusahaan Manufaktur yang Terdaftar di Bursa Efek Jakarta Periode 2001-2004)", SinopsisumNasional Akuntansi 9 Padang. pp.23-26. Suryono, H., dan Prastiwi, A, (2011), "Pengaruh Karakteristik Perusahaan Dan Corporate Governance(Cg) Terhadap Praktik Pengungkapan Sustainability Report (SR) ( Studi Pada Perusahaan - Perusahaan yang Listed (Go-Public) di Bursa Efek Indonesia (BEI) Periode 2007 - 2009 )", Simposium Nasional Akuntansi XIV Aceh 2011, 21-22.

Syahrir. R. K dan Suhendra. S. 2010. "The Effect of Company Characteristic to Disclosure Fitiings of Miscellanous Industry Sector Annual Reports Which is Registered in IDX",Tesis Magister Akuntansi, Universitas Gunadarma.

Tarmizi, Rosmiaty, Octavianti, Devi dan Anwar Chairul. 2012, “Analisis Pengungkapan Akuntansi Lingkungan terhadap Pertanggungjawaban Sosial Industri Kimia (Studi kasus pada Sosial Industri Kimia di Kota Bandar Lampung)", Jurnal Akuntansi dan Keuangan, Vol 3 No.1, hal 21-38.

Tze San, O., Wei Ni, S., Boon Heng, T., dan Sin Huei, N. (2015), "Influence Of Environmental Disclosure On The Financial Performance Of Public Listed Malaysian Manufacturing Companies", Asia-Pacific Management Accounting Journal, Vol 10 No. 1, hal 107-136.

www.walhi.co.id Diakses 10 April pk 12.00 WIB

www.greenpeace.org Diakses 15 April 2017 pk 20.00 WIB 


\section{Lampiran}

Tabel 1.

Statistik Deskriptif Indonesia

\begin{tabular}{|c|c|c|c|c|c|}
\hline & $\mathbf{N}$ & Minimum & Maximum & Mean & Std. Deviation \\
\hline ED & 59 & .03 & .12 & .0686 & .03054 \\
\hline KM & 59 & .01 & 36.60 & 4.5873 & 7.66948 \\
\hline UDK & 59 & 1.00 & 13.00 & 3.8475 & 2.26528 \\
\hline JRDK & 59 & 2.00 & 6.00 & 4.1186 & 1.21889 \\
\hline SIZE & 59 & 18.68 & 30.19 & 25.2274 & 3.09488 \\
\hline ROA & 59 & .01 & 52.00 & 5.5134 & 8.38158 \\
\hline CR & 59 & .75 & 429.93 & 94.0383 & 114.21667 \\
\hline $\begin{array}{c}\text { Valid N } \\
\text { (listwise) }\end{array}$ & 59 & & & & \\
\hline
\end{tabular}

Tabel 2.

Statistik Deskriptif Malaysia

\begin{tabular}{|c|c|c|c|c|c|}
\hline & $\mathbf{N}$ & Minimum & Maximum & Mean & Std. Deviation \\
\hline ED & 63 & .06 & .09 & .0605 & .00378 \\
\hline KM & 63 & .01 & 61.12 & 10.0932 & 17.19285 \\
\hline UDK & 63 & 2.00 & 11.00 & 4.7460 & 2.10964 \\
\hline JRDK & 63 & 2.00 & 8.00 & 4.5714 & 1.29159 \\
\hline SIZE & 63 & 16.36 & 26.31 & 19.9959 & 1.66976 \\
\hline ROA & 63 & .01 & 9.14 & .3213 & 1.36945 \\
\hline CR & 63 & .39 & 25.70 & 2.1797 & 3.10021 \\
\hline Valid N (listwise) & 63 & & & & \\
\hline
\end{tabular}

Tabel 3.

Uji Signifikansi Parameter

Individual (Uji t) Indonesia

\begin{tabular}{|c|c|c|c|c|}
\hline Variabel & koefesien & $\mathbf{t}$ & Sig. & Simpulan \\
\hline KM & -.322 & -2.792 & .007 & Ditolak \\
\hline UDK & .297 & 2.620 & .011 & Diterima \\
\hline SIZE & .089 & .758 & .452 & Ditolak \\
\hline CR & -.333 & -2.836 & .006 & Ditolak \\
\hline
\end{tabular}


Tabel 4.

Uji Signifikansi Parameter Individual (Uji t) Malaysia

\begin{tabular}{|c|c|c|c|c|}
\hline Variabel & koefesien & $\mathbf{t}$ & Sig. & Simpulan \\
\hline KM & .090 & 3.239 & .002 & Diterima \\
\hline UDK & .023 & .769 & .445 & Ditolak \\
\hline SIZE & .091 & 3.056 & .003 & Diterima \\
\hline CR & .992 & 36.053 & .000 & Diterima \\
\hline
\end{tabular}

Tabel. 5

Hasil Uji Group

\begin{tabular}{|l|l|r|r|r|r|}
\hline \multicolumn{7}{|c|}{ Group Statistics } \\
\hline & Negara & \multicolumn{1}{c|}{$\mathrm{N}$} & Mean & Std. Deviation & \multicolumn{1}{c|}{ Std. Error Mean } \\
\hline ED & Indonesia & 59 & .0686 & .03054 & .00398 \\
\hline & Malaysia & 63 & .0605 & .00378 & .00048 \\
\hline
\end{tabular}

Tabel 6.

Hasil Uji Levene's Independent

Samples Test

\begin{tabular}{|c|c|c|c|c|c|c|c|c|c|}
\hline & $\begin{array}{r}\text { Levene's } \\
\text { for Equali } \\
\text { Varianc }\end{array}$ & $\begin{array}{l}\text { Test } \\
\text { ty of } \\
\text { es }\end{array}$ & \multicolumn{7}{|c|}{ t-test for Equality of Means } \\
\hline & \multirow[t]{2}{*}{ 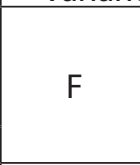 } & \multirow[t]{2}{*}{ Sig. } & \multirow[t]{2}{*}{ T } & \multirow[t]{2}{*}{ Df } & \multirow[t]{2}{*}{$\begin{array}{c}\text { Sig. } \\
\text { (2-tailed) }\end{array}$} & \multirow[t]{2}{*}{$\begin{array}{c}\text { Mean } \\
\text { Difference }\end{array}$} & \multirow[t]{2}{*}{$\begin{array}{l}\text { Std. Error } \\
\text { Difference }\end{array}$} & \multicolumn{2}{|c|}{$\begin{array}{l}95 \% \text { Confidence } \\
\text { Interval of the } \\
\text { Difference }\end{array}$} \\
\hline & & & & & & & & Lower & \begin{tabular}{|l|} 
Upper \\
\end{tabular} \\
\hline \begin{tabular}{|l|} 
Equal \\
variances \\
assumed \\
\end{tabular} & 163.410 & .000 & 2.106 & 120 & .037 & .00817 & .00388 & .00049 & 01585 \\
\hline \begin{tabular}{|l|} 
Equal \\
variances \\
not \\
assumed \\
\end{tabular} & & & 2.040 & 59.665 & .046 & .00817 & .00400 & .00016 & .01618 \\
\hline
\end{tabular}

